\title{
A pequena Bridges e seu grande feito.
}

\section{Determinação e persistência na luta dos afro-americanos pelos direitos civis nos Estados Unidos na década de 1960}

\author{
Resenha do livro infanto-juvenil de Madeline Donaldson. Ruby Bridges, New York: \\ Barnes \& Noble, 2009. (History Maker Bios Series)
}

Elena Pajaro Peres ${ }^{1}$

Há muitas possibilidades para se iniciar uma biografia, dependendo dos objetivos do autor, do público que se queira atingir, das especificidades da vida do biografado. Entretanto, Madeline Donaldson, em seu livro infanto-juvenil, escolheu um caminho peculiar e instigante: começar descrevendo uma única fotografia preto e branco, que retrata a pequena afroamericana Ruby Bridges descendo as escadas da escola pública William Frantz na cidade norteamericana de New Orleans, em 1960. A imagem da menina de apenas seis anos, com seu vestidinho branco, um grande laço de fita nos cabelos, de mão dadas com sua mãe e cercada por oficiais da polícia federal, marca um evento singular para que se possa compreender o contexto sócio, político e cultural dos Estados Unidos no período: o primeiro dia em que uma criança afrodescendente, enfrentando todas as manifestações em contrário, pôde cruzar os portais daquela conceituada escola no Estado da Louisiana. A escolta policial, mantida durante a maior parte do ano letivo, garantia a segurança de Bridges contra a fúria de um grupo de pessoas indignadas com a presença de uma menina negra na escola antes reservada aos brancos.

Donaldson, após uma breve introdução, narra, nas páginas seguintes, os acontecimentos na vida de Bridges diretamente articulados à história dos negros norteamericanos na segunda metade do século XX e sua luta por uma educação escolar de qualidade e integrada, sem distinções raciais. Ficamos sabendo logo no início do livro que Bridges nasceu em 1954, no mesmo ano que a Suprema Corte dos Estados Unidos determinou em nível federal o fim das escolas segregadas. Porém sua família vivia naquela data no Estado do Mississippi, no Sul do país, região tradicionalmente marcada pela separação entre brancos e negros e que possuía leis próprias que bloqueavam qualquer avanço nesse aspecto. Seus avós eram trabalhadores rurais que cultivavam terras pertencentes a fazendeiros que, em troca da concessão, recebiam boa parte da renda da colheita. O problema maior era que esses fazendeiros podiam, a qualquer momento, exigir a devolução do terreno. Fugindo dessa constante instabilidade, seus pais, que também trabalhavam na fazenda, resolveram migrar para New Orleans em 1958, em busca de uma vida melhor. Começava assim a saga de Bridges, que foi um exemplo da saga coletiva de todos os afro-americanos por oportunidades iguais.

O livro de Donaldson segue o caminho da protagonista, permeando a narração com muitas fotografias históricas e ilustrações, numa edição primorosamente elaborada. Em

${ }^{1}$ Pós-doutoranda no Instituto de Estudos Brasileiros da Universidade de São Paulo, com bolsa FAPESP. Doutora em História pela Universidade de São Paulo. 
algumas delas podemos ver a ação da N.A.A.C.P. (National Association for the Advancement of Colored People), associação pelos direitos civis fundada em 1909, responsável por aplicar o teste de conhecimentos que permitiu que Ruby fosse admitida na William Frantz Public School.

Era apenas o início de uma série de confrontos que seriam enfrentados pela pequena Bridges ao ultrapassar uma linha de segregação imposta historicamente. Nos meses que se seguiram, Ruby tinha na classe apenas a companhia de sua professora, Barbara Henry, que também sofreu discriminação por aceitá-la como aluna. Os pais que gritavam do lado de fora, recusavam-se a deixar que seus filhos estudassem ao lado de uma criança negra. Foram dias difíceis, mas aos poucos os protestos foram perdendo a força, Ruby persistiu em sua jornada e os alunos brancos retornaram às salas de aula. No ano seguinte, outros afro-americanos foram admitidos na mesma escola, dando mais força à postura sempre determinada de Ruby. A narrativa prossegue, relatando a vida adulta de Ruby Bridges até se tornar uma ativista e líder comunitária em New Orleans, lutando pela reconstrução das escolas após a devastação deixada pelo furacão Katrina em 2005.

Outros livros já haviam colocado a história de Bridges em discussão dentro do universo das leituras infantis: The Story of Ruby Bridges, de Robert Coles, publicado em 1995, e os livros escritos pela própria Ruby Bridges: Through My Eyes, de 1999, e Ruby Bridges Goes to School. My True Story, de 2003. Em 1998 foi lançado o filme A história de Ruby Bridges, dirigido pela cineasta caribenha Euzhan Palcy. O pequeno livro de Madeline Donaldson vem se somar a esses esforços mantendo uma abordagem crítica e provocativa. Desperta a curiosidade, mas também afirma posições, o que é bastante oportuno por derrubar preconceitos de que livros destinados a crianças e adolescentes devam ser insípidos em relação ao seu teor político. Ele relembra a história e mostra como a tarefa de Bridges foi cumprida. Ela, como seu próprio sobrenome sugere, estabeleceu pontes entre um mundo marcado pela segregação oficializada na forma de lei e um outro mundo, em que esta mesma segregação passou a ser punida pela lei. Não foi fácil atravessar essa ponte e as conquistas constantemente são reavaliadas para a definição do quanto ainda é necessário caminhar para se chegar a uma margem mais firme de igualdade de direitos e oportunidades, deixando para trás definitivamente o reino da supremacia branca. O livro Ruby Bridges contribui para que novas gerações levem adiante essa reflexão e não se limita à faixa etária para a qual foi destinado. 